\title{
Differences in the experiences of reading medical records online: elderly, older and younger adults compared
}

\author{
Isto Huvila \\ Uppsala University \& Åbo Akademi University \\ isto.huvila@abm.uu.se \\ https://orcid.org/0000-0001-9196-2106 \\ Kristina Eriksson-Backa \\ Åbo Akademi University \\ kristina.eriksson-backa@abo.fi \\ https://orcid.org/0000-0002-0583-2354 \\ Jonas Noll \\ Uppsala University \\ jonas.moll@it.uu.se \\ https://orcid.org/0000-0002-4772-4730 \\ Gunilla Myreteg \\ Uppsala University \\ gunilla.myreteg@fek.uu.se \\ https://orcid.org/0000-0003-1272-4068 \\ Maria Hägglund \\ Uppsala University \\ maria.hagglund@kbh.uu.se \\ https://orcid.org/0000-0002-6839-3651
}

Keywords: medical records; information behaviour; age; experiences; ehealth 
Even if there is a lot of literature on health information behaviour and some research comparing age groups (e.g. Ek, 2013; Lustria, Smith, \& Hinnant, 2011), the understanding of the differences between age groups is still incomplete. Earlier age-related research has tended to focus on the oldest (e.g., Yates et al., 2012; Enwald et al., 2017; Eriksson-Backa, Enwald, Hirvonen, \& Huvila, 2018) and young citizens (e.g., Beck et al., 2014; Galeshi, Sharman, \& Cai, 2018; Hirvonen et al., 2016; Martínez-Martinez, González, \& Cambra, 2018), while especially the older adults, who are still active in working life but approaching retirement, have received only limited attention (Huvila, Daniels, Cajander, \& Åhlfeldt, 2016; Huvila et al., 2018). A survey with Swedish patients who had read their medical record online using the national e-health portal Journalen was conducted in 2016 to map the experiences of older adults (born 1946-1960) using medical records based e-health and information services in comparison to elderly and younger patients.

\section{Material and methods}

The study is based on a national survey of patients in Sweden. The survey was designed on the basis of previous interview and survey studies with patients and health care professionals (e.g., Grünloh, Cajander, \& Myreteg, 2016; Huvila, Cajander, Daniels, \& Åhlfeldt, 2015; Huvila et al., 2016; Rexhepi, Åhlfeldt, Cajander, \& Huvila, 2016; Scandurra, Jansson, Forsberg-Fransson, \& Ålander, 2015). The data were collected between June and October, 2016. The survey was accessible in the e-health portal Journalen, which is a part of the larger national e-health portal $1177 . \mathrm{se}$, in Sweden. In total, 423,141 patients logged into Journalen during the study period and had access to the survey. Of the 2587 patients who completed the survey, $62.97 \%(1,629 / 2587)$ were women, $30.85 \%$ men $(798 / 2587)$ and $0.4 \%$ identified themselves as other (10/2587).

The data have been preliminarily analysed with SPSS 25.0 using KruskalWallis and Pearson Chi-Square tests with a $95 \%$ confidence interval to study how the group of respondents labelled as Older Adults, born 1946-1960 (by the time of data collection between 55 and 72 years old) differ from those born after 1960 (i.e., younger than 55 by the time of data collection) labelled as Young Adults, and those born before 1946 (older than 72 when the data was collected) labelled as Elderly. The number of respondents in each of these groups are presented in table 1. 
Table 1: Number of respondents in each of the studied groups; Older Adults, Young and Elderly

\begin{tabular}{llc}
\hline Age group & $\mathrm{n}$ & $\%$ \\
\hline Older Adults & 707 & 27.33 \\
Young Adults & 1413 & 54.62 \\
Elderly & 330 & 12.76 \\
No answer & 137 & 5.30 \\
\hline
\end{tabular}

\section{Preliminary findings}

A preliminary analysis of the data suggests that there are several differences between the age groups regarding how they experience reading their medical records in Journalen. Moreover, the analysis does not reveal any clear overarching pattern concerning the relationship between skills and experiences in comparison to the respondents' age.

The findings indicate that a more elaborate analysis of age-related differences in the experiences of using e-health services is needed in order to better understand user needs. This knowledge can, furthermore, be used to inform the development of new services as well as for refining the existing ones.

\section{References}

Beck, F., Richard, J.-B., Nguyen-Thanh, V., Montagni, I., Parizot, I., \& Renahy, E. (2014). Use of the internet as a health information resource among french young adults: Results from a nationally representative survey. Journal of Medical Internet Research, 16(5). https://doi. org/10.2196/jmir. 2934

Ek, S. (2013). Gender differences in health information behaviour: A finnish population-based survey. Health Promotion International, 30(3), 736-745. https://doi.org/10.1093/heapro/ dat063

Enwald, H., Kangas, M., Keränen, N., Immonen, M., Similä, H., Jämsä, T., \& Korpelainen, R. (2017). Health information behaviour, attitudes towards health information and motivating factors for encouraging physical activity among older people: Differences by sex and age. In Information research (Vol. 22, p. isic1623). University of Borås. http://www. informationr. net/ ir/22-1/isic/isic1623.html

Eriksson-Backa, K., Enwald, H., Hirvonen, N., \& Huvila, I. (2018). Health information seeking, beliefs about abilities, and health behaviour among finnish seniors. Journal of Librarianship and Information Science, 5o(3), 284-295. https://doi.org/10.1177/0961000618769971

Galeshi, R., Sharman, J., \& Cai, J. (2018). Influence of ethnicity, gender, and immigration status on millennials' behavior related to seeking health information: Results from a national survey. Equality, Diversity and Inclusion: An International Journal, 37(6), 621-631. https://doi .org/ 10.1108/EDI-05-2017-0102 
Grünloh, C., Cajander, Å., \& Myreteg, G. (2016). “The record is our work tool!”-physicians' framing of a patient portal in sweden. Journal of Medical Internet Research, 18(6), e167. https: //doi.org/10.2196/jmir. 5705

Hirvonen, N., Ek, S., Niemelä, R., Pyky, R., Ahola, R., Korpelainen, R., \& Huotari, M.-L. (2016). Everyday health information literacy in relation to health behavior and physical fitness: A population-based study among young men. Library \& Information Science Research, 4(38), 308-318. https://doi.org/10.1016/j.lisr.2016.11.013

Huvila, I., Cajander, Å., Daniels, M., \& Åhlfeldt, R.-M. (2015). Patients' perceptions of their medical records from different subject positions. Journal of the Association for Information Science and Technology, 66(12), 2456-2470. https://doi.org/10.1002/asi.23343

Huvila, I., Daniels, M., Cajander, Å., \& Åhlfeldt, R.-M. (2016). Patients reading their medical records: Differences in experiences and attitudes between regular and inexperienced readers. Information Research: An International Electronic Journal, 21(1). https://eric.ed.gov/?id= EJ1094574

Huvila, I., Enwald, H., Eriksson-Backa, K., Hirvonen, N., Nguyen, H., \& Scandurra, I. (2018). Anticipating ageing: Older adults reading their medical records. Information Processing \& Management, 54(3), 394-407. https://doi.org/10.1016/j.ipm.2018.01.007

Lustria, M. L. A., Smith, S. A., \& Hinnant, C. C. (2011). Exploring digital divides: An examination of eHealth technology use in health information seeking, communication and personal health information management in the usa. Health Informatics Journal, 17(3), 224-243. https://doi. org/10.1177/1460458211414843

Martínez-Martinez, L., González, J. I. N., \& Cambra, U. C. (2018). Preferences of young people in the use of facebook as a health education tool for hpv. European Journal of Interdisciplinary Studies, 4(1), 49-56. https://doi.org/10.26417/ejis.v10i1.p49-56

Rexhepi, H., Åhlfeldt, R.-M., Cajander, Å., \& Huvila, I. (2016). Cancer patients' attitudes and experiences of online access to their electronic medical records: A qualitative study. Health Informatics Journal, 24(2), 115-124. https://doi.org/10.1177/1460458216658778

Scandurra, I., Jansson, A., Forsberg-Fransson, M.-L., \& Ålander, T. (2015). Is "patient's online access to health records" a good reform? - opinions from swedish healthcare professionals differ. Procedia Computer Science, C(64), 964-968. https://doi.org/10.1016/j.procs. 2015. 08.614

Yates, C., Stoodley, I., Partridge, H., Bruce, C., Cooper, H., Day, G., \& Edwards, S. L. (2012). Exploring health information use by older australians within everyday life. Library Trends, $60(3)$, 460-478. https://doi.org/10.1353/lib.2012.0004 